\title{
Human, Technical, and Organizational Drivers Affecting Sustainability of Content Firms through Management and Innovation Capability during COVID-19
}

\author{
Hyunsun Park ${ }^{1}$, Sanghyun Kim ${ }^{1, *}$, Moonjong Choi ${ }^{2}$ and Jaesung Choi ${ }^{3}$ \\ 1 School of Business Administration, Kyungpook National University, Daegu 41566, Korea; \\ pullip83@hanmail.net \\ 2 Daegu Center for Creative Economy and Innovation, 51, Hoam-ro, Daegu 41585, Korea; mjchoi0@gmail.com \\ 3 Department of Computer Science and Engineering, Sunmoon University, Asan-si 31460, Korea; \\ jschoi@sunmoon.ac.kr \\ * Correspondence: ksh@knu.ac.kr; Tel.: +82-53-950-5877
}

Citation: Park, H.; Kim, S.; Choi, M.; Choi, J. Human, Technical, and Organizational Drivers Affecting Sustainability of Content Firms through Management and Innovation Capability during COVID-19. Sustainability 2021, 13, 6661. https:// doi.org/10.3390/su13126661

Academic Editor: Lorenzo Ardito

Received: 8 May 2021

Accepted: 7 June 2021

Published: 11 June 2021

Publisher's Note: MDPI stays neutral with regard to jurisdictional claims in published maps and institutional affiliations.

Copyright: (c) 2021 by the authors. Licensee MDPI, Basel, Switzerland. This article is an open access article distributed under the terms and conditions of the Creative Commons Attribution (CC BY) license (https:// creativecommons.org/licenses/by/ $4.0 /)$.
Abstract: Individuals and businesses engage in a number of activities in the digital environment. During unexpected circumstances, such as COVID-19, many people used the internet for purposes such as education, work, and entertainment. This has led to a rapid growth in the content industry. Thus, studies of the sustainability and success of content companies are essential. Few empirical studies focus on these aspects of content companies, particularly concentrating on the importance of management and innovation capability. This study examines the roles of management and innovation capabilities and the human, technical, and organizational factors that affect these capabilities. This, in turn, positively affects the sustainability and success of content companies. The proposed research model includes content development ability and leadership as a human factor, technical support and information technology (IT) infrastructure as a technical factor, and top management and financial support as an organizational factor. A total of 255 responses were collected from upper management-level employees at various firms in the content industry. Covariance-based structural equation modeling was used with Amos 22.0. The results indicated that all proposed hypotheses were supported with the exception of the hypothesis that tests the relationship between content development and management capability. The study findings provide information necessary for future sustainability and success of content companies.

Keywords: human factor; technical factor; organizational factor; management capability; innovation capability; sustainability of content business

\section{Introduction}

The rapid progress of the Fourth Industrial Revolution has blurred the boundaries between online and offline, and between industries. Thus, firms have developed new technologies that have changed the digital environment and content usage. In response to these changes, countries are actively promoting digital policies or large-scale investments [1]. For example, the United States has been promoting digital innovation policies as a key driver of economic growth in the early years. China is securing global market share through large-scale investments in digital infrastructure and ecosystems. Europe is promoting government-led digitization and investments in technology development. The digital environment is changing rapidly, and the digital transformation is expected to accelerate as information and communication technologies (ICTs) continue to develop and commercialize related technologies [2].

Rapid digital transformation and digitization is creating new business models and changing market competitiveness. Unexpected circumstances, such as the COVID-19 pandemic and changing consumer lifestyles, have led to an accelerated digital transformation [3]. This transformation has been advanced due to the "untact" lifestyle, which means 
no contact that has resulted in firms rethinking their business strategies to remain sustainable. Untact is a term commonly used after COVID-19, which segregates buyers from unwanted contact. As the untact culture prevails, people are changing the way they buy and consume products or services based on ICT [4]. The untact life impacts digital firms, society, and industries. It accelerates digital transformation. Consequently, growth and sustainability opportunities for digital content companies are increasing. In other words, as individuals' lives are changed, becoming untact due to COVID-19, individuals are more often exposed to various types of digital content. Therefore, the development of capabilities necessary for content companies to meet the increasing demand of customers is essential for corporate sustainability, even after the COVID-19 pandemic [4].

Digital content is a generic term for content that digitizes various types of information such as text, audio, and video that existed in analog form in bit (0 and 1) units [5]. Analog information processed in a digital form using ICT is digital content. The popularity of smart devices and the commercialization of 5G services have transformed consumers' content behavior. Besides, the untact culture is an opportunity for further growth of the digital content industry. Technologies such as virtual reality (VR) and augmented reality (AR) can be realized through faster $5 \mathrm{G}$ services that allow people to realistically immerse themselves in the content. The ease of content sharing is a unique feature of digital content [5]. Accordingly, various digital content markets such as music, TV broadcasts, videos, games, education, and digital books are expanding rapidly. Furthermore, various platforms and new business models for creating and distributing digital content are emerging [6]. Not only does the basic content interact organically, but the platform, network, and devices also do. Through their value chain relationship, the components form a content-oriented ICT ecosystem.

Recently, global platforms such as YouTube and Netflix have grown rapidly, boosted the overseas expansion of domestic content and intensified competition for international content distribution. Platforms that distribute content are becoming more diverse, and consumers can find the content they want through the platforms at any time. Based on this, the digital content market might increase at an annual rate of $9.2 \%$, accounting for $58.2 \%$ of the global content market by 2022. As the consumption of digital content increases, a new market with a high added value might emerge from the convergence of new technologies and other industries [6].

Therefore, companies that plan, produce, and distribute content are planning various strategies based on the axis of digitalization and globalization. In addition, governments in many countries feel the need for national strategies to lead the paradigm shift in the content industry and are preparing related support. Most digital content operates on the basis of ICT networks and platforms. Thus, an enterprise's content platform strategy is important. In addition, the steady growth of content requires an appropriate platform and corporate strategy. In other words, achieving an edge in platform competition and creating new content require companies to plan, produce, and distribute digital content. Despite the increasing influence of the content industry, such as digitization of content and convergence with various industries, studies on what factors companies should consider for sustainability and successful content are limited. Competition among content companies is intensifying, and the global market size is also increasing. However, most content companies have structural problems such as a weak investment base, IT infrastructure, and a lagging platform distribution environment [7]. Therefore, there are limitations with content companies maintaining competitiveness and sustaining content growth. In this study, the sustainability of content companies is different from the traditional meaning of sustainability in terms of their ability to adapt well to the rapidly changing hypercompetitive business environment and to have international competitiveness. In other words, the sustainability of a content company means a successful content company operation by improving the factors (e.g., market share, sales, and profits) that can evaluate the company's sustainability by developing various capabilities of the organization. 
This study proposes a model that explains the relationship between a company's capabilities and its digital content sustainable growth factors and empirically analyses the relationship. This study describes a company's management and innovation capability and its human, technical, and organizational factors and examines the relationship between them. It also considers the relationship between the company's capabilities and sustainable growth. To verify the relationship, this study collected offline data from related companies in the content industry. The data were then analyzed using a structural equation modeling (SEM) approach. The study's results suggest the requisite capabilities that digital content companies need for sustainable growth. Moreover, this study makes academic and practical contributions by presenting the basis on which a company's human, technical, and organizational factors affect a company's capabilities.

\section{Literature Review and Hypotheses Development}

\subsection{The Proposed Research Model}

The Fourth Industrial Revolution and the increased popularity of smart devices have defined the digital content industry as the next-generation core value-added industry. The use of digital content is expanding to all industries, and its related content is continuously planned, produced, and distributed. There is an increased emphasis on a corporate strategy for the sustainable growth of content companies as digital content consumption increases. Therefore, an in-depth study on providing a strategy framework for content companies is needed.

Although there are ongoing technical and explanatory discussions on digital content, few studies focus on corporate competency related to strategy. Therefore, this study empirically verifies the factors affecting competence in terms of business management and innovation capabilities for the sustainable growth of content companies [8,9]. From this point of view, we used a psycho-socio-technical process embedded within an organizational structure by Damaševičius [10], which is proposed as an approach that must be considered in leading organizational success through the development and analysis of existing software and strengthening the organization's information technology capabilities. Based on this, human, technical, and organizational factors were proposed as important factors in enhancing the competency of content companies. Since the organizational competency of a content company does not consist of specific elements inside and outside the organization, in order to create results through strengthening the organizational competency, environmental factors inside and outside the organization and the technicalnon-technical (management) aspects must be considered together [11].Thus, we adopted a psycho-socio-technical factors, represented by human, technical, and organizational factors in this study and investigate the relationship between management and innovation capabilities. In order for content companies to continue to grow, they must first be based on their management capability and innovation capability to lead new and innovative technologies and content. Capabilities are built into the organization, are non-transferable, and are considered company-specific; therefore, if utilized, they have properties that can lead to a company-level competitive advantage. IT-based capabilities are generally studied using resource-based view (RBV) theory [12], which looks at companies as to the available resources and how these resources can be combined into effective growth strategies and corporate diversification. A variety of resources must be utilized to support a company's capabilities, and the company's sustainability will be greater through capacity building $[13,14]$. According to studies on business administration, human factors include content development ability and leadership [15], technical factors include technical support and IT infrastructure [16,17], and organizational factors include top management support and financial support [18]. First, planning and developing attractive content that will attract consumption requires human resources with ideas and development capabilities for new content and leadership to actively develop content [19]. From this point of view, Kim [20] indicates that, for the development of information technology used by the organization or for strengthening the overall capacity of the organization, the competence of each member 
of the organization is a very important factor in the human element of the organization, and such member capability is an essential consideration in organization-related research. In particular, because the fusion of individual competencies of organizational members is a very big advantage to the organization, employee competencies are very important to human factors [21].

In addition to the capability of employees, another element of human factor is leadership, which is defined as the extent of an organization member's ability to use proper technology and influence others to achieve goals and develop content. Jeong [22] argues that employee leadership is a variable that must be considered as a human factor in organizational unit studies, and is a very important factor for reinforcing an organization's managerial and innovative capabilities, more than any other factors related to human factors. In other words, the role of individual members of the organization as leaders is a variable that must be included in organizational unit studies in various industries [23].

Second, technical support is needed to develop new content, and appropriate content development can only be made when related IT infrastructure is in place [24,25]. Among the various variables of technical factors, the importance of technical support and IT infrastructure of content companies is being emphasized in many studies. For example, Choi and Kim [26] claimed that technical capabilities such as hardware, software, networks, and databases in general must be included in organizational unit studies. In addition to those technical parts of technical factor, non-technical aspects such as support from the IT department and policies and procedures of tasks using technologies within the organization must be included in the research, using the technical element as an important variable [27].

Finally, the top management's support and financial support suggested by the organizational factor are variables that play a vital role in strengthening the capabilities of content companies [28]. In other word, managerial support and funding is needed to encourage and support content planning and development [29]. If this support is not properly provided in the global platform era, it can be an obstacle to competitive content production and the continued growth of companies. This study examines the impact of management and innovation capabilities on the "sustainability of content firms" based on the literature [30]. Figure 1 describes the research model with the proposed hypotheses.

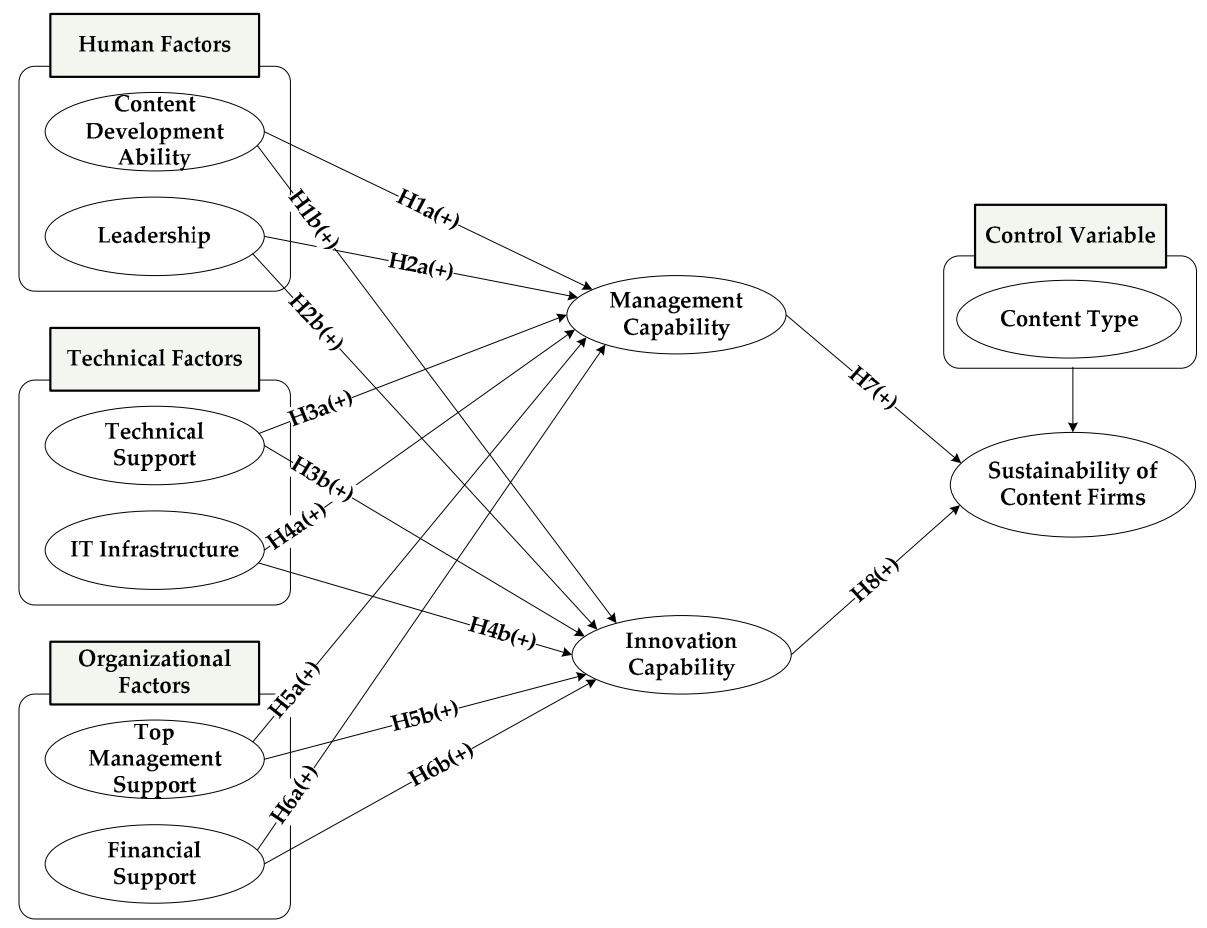

Figure 1. Research model and the proposed hypotheses. 


\subsection{Hypotheses Development}

\subsubsection{Human Factors}

Studies have stressed human factors in the use of various information technologies, for organizational capacity building, and in sustainability. For example, Peng et al. [31] found that the human factor is a crucial and proven determinant for the success of IT outsourcing. This study also proposed that a human factor strengthens the capability of content firms. The human factor includes content development ability and leadership as two important variables that content firms need to be competitive in their industry [32]. Content development ability is defined as the organization member's ability to plan and handle content. When the development capabilities of each member of the organization related to content development (planning, skills, data analysis, etc.) are well-harmonized, the overall content development management capability in the organization is enhanced. Chae et al. [33] claimed that if several companies acquire a set of individuals with excellent capabilities and if a system is built in which the capabilities of these individuals can be harmonized, the chances for the organization's success and sustainability are greater. Based on these claims, Hypotheses H1A and H1B were proposed.

Hypothesis 1A (H1A). Content development ability has a positive effect on management capability.

Hypothesis 1B (H1B). Content development ability has a positive effect on innovation capability.

This study proposes employees' leadership as another crucial human factor in many organizational settings. Prior studies have emphasized the role and importance of employees' leadership in today's business. For example, Tubbs and Schulz [34] defined leadership as an invisible power that influences others to achieve organizational goals. Bueno and Tubbs [35] used the term e-leadership as a leader's ability to use information technology (IT) to accomplish organizational goals. Based on these operational definitions, we defined leadership as the extent of an organization member's ability to use proper technology and influence others to achieve goals and develop content. Here, leadership is a concept applied to individual members except for the top managers of the organization. Leadership is often discussed in coordination with capabilities [35]. Alternatively, managers and members of the organization must have the knowledge, skills, and ability needed for the leadership role. In content development, members should know the content development plan, be able to develop process, and use IT appropriately for development.

Such leadership strengthens content management and innovation capabilities, which are key to the success and sustainability of content companies. From this perspective, Goleman et al. [36] argued that the diverse competencies of leadership make it easier for organizations to develop the overall organizational competencies required to achieve their goals. In the content industry, diverse but similar content is common, and highly innovative content based on a systematic process for content development and management strengthens the companies' competitive advantage. Accordingly, Goleman et al. [36] argued that the leadership of individual members is essential for a systematic process or an organizational capability of content development management. Therefore, the synergy derived from linking various effects resulting from leadership with content development management and content innovation capabilities enables effective decisions in content planning and development. This impacts the sustainability of content companies. Hypotheses H2A and $\mathrm{H} 2 \mathrm{~B}$ were established based on these claims.

Hypothesis 2A (H2A). Leadership has a positive effect on management capability.

Hypothesis 2B (H2B). Leadership has a positive effect on innovation capability.

\subsubsection{Technical Factors}

Technical support and IT infrastructure are essential for revitalizing and internalizing the management and innovation capabilities within content firms. Although studies have highlighted several aspects of technical impact in various organizational contexts, no studies have empirically examined the role of technical factors in relation to content 
firms' management and innovation capability [36]. Technical support refers to the IT skills required for the organization to develop and manage content and the knowledge acquisition ability of the IS department. The organization members' or the IS department's ability to acquire new technical and other skills related to content development is important for a company's content development management and new content development capabilities. Thus, Shah and Bandi [37] argued that an organization's capability is influenced by technical support from the IS department. Furthermore, the availability of various technical supports, including planning and developing new content and problem solving when developing content, strengthen the management and innovation capability of the content [38]. Therefore, technical factors related to two main capabilities in content development were conceptualized as direct effects, and this study suggested hypotheses H3A and H3B.

Hypothesis 3A (H3A). Technical support has a positive effect on management capability.

Hypothesis 3B (H3B). Technical support has a positive effect on innovation capability.

IT infrastructure is another technical variable. It refers to an organization's level of technical and procedural IT infrastructure for content development and management. IT infrastructure is often represented through technical aspects, but this study also includes procedural elements. Technological infrastructure enhances the organization's ability to manage all processes related to content development, and the possibility of using new technologies enables innovative content development [38]. Moreover, IT infrastructure creates an internal network in which employees can access and share data and information for managing content development. This enhances management capability for content planning and development. To increase the organization's management and innovation content development management capability, a policy or procedure for planning and managing content other than technical IT infrastructure must be developed.

Bryd and Turner [39] claimed that the two broadly defined infrastructures relate to the technical and the human or procedural aspects. Technical IT infrastructure includes hardware (HW)/software (SW), network, and other tangible IT resources, while human or procedural infrastructure implies the knowledge, skills, and policies required to plan, manage, and develop IT resources within an organization. Therefore, both the technical and nontechnical elements of IT infrastructure should be studied. These infrastructures significantly improve the organization's management and innovation capabilities [40]. Hypotheses H4A and H4B were proposed to empirically demonstrate the impact of IT infrastructure on the management and innovation capability of a content firm based on these claims.

Hypothesis 4A (H4A). Information technology infrastructure has a positive effect on management capability.

Hypothesis 4B (H4B). Information technology infrastructure has a positive effect on innovation capability.

\subsubsection{Organizational Factors}

The two variables necessary for the organizational factor are top management and financial support. First, studies (e.g., [41,42]) have defined top management support as the extent to which an organization's top management recognizes the importance of specific functions such as marketing and IT and is personally involved with those practices. We, therefore, define top management support as the degree of active support and involvement from top managers in developing and managing new content. IT research has long emphasized the importance of top management support. Particularly, Lee et al. [42] claimed that many studies have consistently emphasized the importance of top management support for strengthening the organization's diverse capabilities and the success and sustainability of any organization in many industries.

Consequently, Ramirez Lopez and Grijalba Castro [43] emphasized that content firms should shorten the distance between top management and activities or projects to achieve 
success and sustainability. Moreover, a supportive management attitude creates an environment where members of the organization are recognized and appreciated for their work. This motivates them to perform better [44] and, in turn, leads to a successful and sustainable business. Although each employee is important to the success and sustainability of an organization, top management anchors the operation of the organization. Without top management support, the organization's growth is hindered regardless of the employees' abilities in content development. Hypotheses H5A and H5B were therefore established.

Hypothesis 5A (H5A). Top management support has a positive effect on management capability. Hypothesis 5B (H5B). Top management support has a positive effect on innovation capability.

The second organizational factor is financial support, which is defined as the financial cost incurred by an organization to develop and manage new content. Studies (e.g., Tu et al. [44]) found that financial support is crucial for an organization's success and increased sustainability in the organization's operations. Furthermore, in the study of blockchain-based intelligent transportation systems, Çaldağ and Gökalp [45] asserted that financial support is a critical success factor that enables all organizational activities. Chan and Chong [46] argued that financial support is indispensable for an organization's develop management, innovative capabilities, and sustainability. Particularly, content companies must continuously update the content being provided and develop new content. Management and innovation capabilities in content development are essential for increasing the success and sustainability of such contents. Ko et al. [47] claimed that financial support is necessary for the management and innovation capabilities of content development. Shin and Jo [48] argued that content development is a knowledge industry in which human resources are concentrated. Therefore, highly innovative content requires financial input for content developers, content development management, and developer competency enhancement. Therefore, hypotheses H6A and H6B were proposed.

Hypothesis 6A (H6A). Financial support has a positive effect on management capability.

Hypothesis 6B (H6B). Financial support has a positive effect on innovation capability.

\subsubsection{Capability and Sustainability in a Content Firm}

Management capability in a content firm is defined as the ability to effectively manage the content development process. This includes the ability to gather, organize, process, and maintain information required for developing content and the proper use of technology. It also involves implementing planned processes of content development $[9,14]$. Studies have claimed that various organizational management capabilities enhance the performance of a specific project or task. Therefore, effective management throughout the development of new content is important for successful content development and sustainability. Mostafiz et al. [49] argued that content development is based on various stories and that the organization's ability to manage and plan these stories is directly linked to the success of the company. Therefore, management capability plays an important role in continuous content development and in increasing the companies' sustainability. Therefore, hypothesis $\mathrm{H} 7$ was proposed.

Hypothesis 7 (H7). Management capability has a positive effect on sustainability of a content firm.

Zawislak et al. [50] defined innovation capability as the strength or expertise of a bundle of interrelated organizational procedures for developing new products, services, or processes. Uhl and Alexander [51] defined innovation capability as the firm's capability to manage the innovation-related product or business processes essential for a firms' competitiveness. Based on these operational definitions of innovation capability, this study defines innovation capability as a content firm's tangible and intangible capabilities enhanced by various supports that develop innovative contents for increased sustainability in the content industry. 
Innovation capability is crucial for driving sustained growth and building a competitive advantage within the industry [52]. However, innovation capability is a challenge for the content industry because it cannot be built in the short term. For the organization members to become innovative, they must make continuous efforts in human, technical, and environmental fields. Accordingly, Rajapathirana and Hui [53] argued that companies with innovation capabilities have advanced systems in the overall operation and management of the organization. Particularly, innovation is crucial for developing content, which means that most content such as games, education, and stories require developers to be creative. Therefore, developers and managers must create new content that is different from the existing framework for new content development. Accordingly, Romijn and Albaladejo [54] claimed that creative works can achieve greater results only when innovation is supported. Innovation capability is one of the competencies essential for the sustainability of content companies. Therefore, Hypothesis H8 was developed to empirically demonstrate a positive relationship between innovation capability and the sustainability of a content firm.

Hypothesis 8 (H8). Innovation capability has a positive effect on the sustainability of a content firm.

\section{Research Methodology}

\subsection{Participants and Data Collection}

This study used online and offline channels to collect more data at the same time. However, due to the potential issues caused by using two different channels in data collection, online surveys were conducted in the same way as offline surveys. In other words, we went through the following process in collecting data to make sure for online data vulnerabilities (reliability, accuracy, etc.). First, the online survey included a session, explaining aspects of the study such as research backgrounds, research objectives, and terms used in the study, essentially the same process as offline data collection. Through this, the participants of the online survey might have a better understanding of the study so that they could respond to each item with their best knowledge. In addition, to encourage the accurate information of online survey participants, gift certificates were provided by randomly selecting survey participants. Another process we took to ensure the reliability of the online data was the refining process. That is, we confirmed the final online data through a data refinement process that excluded non-response data and those data participants that selected mid-point in the scale for many items that were commonly cons for online data collection.

A total of 300 offline surveys were distributed to rapidly growing content development firms. We received 152 responses from the offline survey, while 123 responses were collected from online. Thus, a total of 275 responses were collected from both online and offline; of which, four responses from offline were excluded because the answers were either incomplete or irrelevant to the context of this study, while 16 responses were discarded from online after refining data. Of the final 255 responses, 107 responses were collected online, and the remaining 148 were collected from offline surveys.

The respondent gender breakdown from participating companies was $59.22 \%$ male and $40.78 \%$ female. The participants' ages were between 26 and 59 years, with a mean age of 37.2 years. More than half of the participants $(58.82 \%)$ had a college/university degree, while $24.31 \%$ respondents had graduate degrees. The positions in which the participants were employed were CEO/executives (27.84\%), head of department or division (34.90\%), senior managers $(21.96 \%)$, junior managers $(11.76 \%)$, and others $(3.53 \%)$. Participating firms provided various content services. Among them, entertainment (games, music, videos, etc.) ranked highest (63.92\%), followed by broadcasting $(47.06 \%)$, and general information (39.61\%). Table 1 profiles the respondents. 
Table 1. Respondent demographic characteristics $(n=255)$.

\begin{tabular}{|c|c|c|c|}
\hline \multicolumn{2}{|c|}{ Demographic Categories } & \multirow{2}{*}{$\begin{array}{c}\text { Frequency } \\
38\end{array}$} & \multirow{2}{*}{$\begin{array}{c}\text { Percentage } \\
14.90 \%\end{array}$} \\
\hline \multirow{4}{*}{ Age } & Under 30 & & \\
\hline & $30-39$ & 70 & $27.45 \%$ \\
\hline & $40-49$ & 82 & $32.16 \%$ \\
\hline & $50+$ & 65 & $25.49 \%$ \\
\hline \multirow{2}{*}{ Gender } & Male & 151 & $59.22 \%$ \\
\hline & Female & 104 & $40.78 \%$ \\
\hline \multirow{4}{*}{ Educational level } & High School & 36 & $14.12 \%$ \\
\hline & College/University & 150 & $58.82 \%$ \\
\hline & Post-Graduate Study & 62 & $24.31 \%$ \\
\hline & Other & 7 & $2.75 \%$ \\
\hline \multirow{5}{*}{ Position } & CEO/Executives & 71 & $27.84 \%$ \\
\hline & Head of Department & 89 & $34.90 \%$ \\
\hline & Senior Managers & 56 & $21.96 \%$ \\
\hline & Junior Managers & 30 & $11.76 \%$ \\
\hline & Others & 9 & $3.53 \%$ \\
\hline \multirow{5}{*}{$\begin{array}{l}\text { Type of content in } \\
\text { service (multiple } \\
\text { choice) }\end{array}$} & Entertainment & 163 & $63.92 \%$ \\
\hline & General Information & 101 & $39.61 \%$ \\
\hline & Education & 86 & $33.73 \%$ \\
\hline & Broadcasting & 120 & $47.06 \%$ \\
\hline & Others & 22 & $8.63 \%$ \\
\hline Total Responses & & 255 & 100.0 \\
\hline
\end{tabular}

\subsection{Measurement Development}

Each construct in the research model was measured on the basis of earlier studies and adapted to include sustainability and success of content companies as key research factors to be evaluated. For example, the items to measure variables in human factors (content development ability and leadership) were developed based on earlier studies [55,56]; similarly, six technical factors were measured that assessed the technical support and IT infrastructure variables using past studies [57,58]. Furthermore, this study adopted and then modified several items to measure top management and financial support included in organizational factors, following the method from $\mathrm{Wu}$ and $\mathrm{Wu}$ [59]. Finally, two capabilities (management and innovation) and the success of content firms were assessed using items based on the studies by Garrison et al. [60] and Rhee and Stephens [61]. All items that measured latent variables were evaluated using a seven-point Likert scale ranging from 1 (strongly disagree) to 7 (strongly agree). Table 2 shows the measurement items with their sources.

Following the initial development of measures, validity was assessed by soliciting inputs from two IS professors, one marketing researcher, and five graduate students who had several years' experience in empirical content research. Feedback and comments were provided on the length and clarity of the items. Then, a pretest $(n=20)$ was conducted to statistically prove the reliability and validity of the measurement model. The data for the pretest were collected from a local university. The results indicate sufficient validity and reliability. 
Table 2. Variables, measures, and related studies.

\begin{tabular}{|c|c|c|c|}
\hline & iable & Items & Related Studies \\
\hline \multirow[b]{2}{*}{ Human Factors } & $\begin{array}{c}\text { Content } \\
\text { Development Ability }\end{array}$ & $\begin{array}{l}\text { We have expertise in content development. } \\
\text { We have content-related knowledge and the ability to } \\
\text { interpret external information well. } \\
\text { We are well-established in our ability to combine, process, } \\
\text { and reinterpret the acquired knowledge. }\end{array}$ & \multirow[b]{2}{*}[55,56]{} \\
\hline & Leadership & $\begin{array}{c}\text { Our leaders: } \\
\text { Show confidence in content planning and development. } \\
\text { Are familiar with the content planning and } \\
\text { development process. } \\
\text { Actively support the use of IT in content planning } \\
\text { and development. }\end{array}$ & \\
\hline \multirow{2}{*}{ Technical Factors } & Technical Support & $\begin{array}{c}\text { Our information systems department: } \\
\text { Can support IT about content whenever needed. } \\
\text { Is well-equipped with information knowledge necessary for } \\
\text { content planning and development. } \\
\text { Is well able to solve the IT problems faced with content } \\
\text { planning and development. }\end{array}$ & \multirow{2}{*}[57,58]{} \\
\hline & IT Infrastructure & $\begin{array}{c}\text { Our organization has: } \\
\text { Enough HW/SW to develop new content. } \\
\text { A high network power for supporting efficient content } \\
\text { development processes. } \\
\text { Well-designed policies and procedures required for } \\
\text { developing content. }\end{array}$ & \\
\hline \multirow{2}{*}{$\begin{array}{l}\text { Organizational } \\
\text { Factors }\end{array}$} & $\begin{array}{c}\text { Top } \\
\text { Management Support }\end{array}$ & $\begin{array}{l}\text { Our management: } \\
\text { Actively provides the resources necessary for } \\
\text { content development. } \\
\text { Are likely to take risks associated with content development. } \\
\text { Actively supports the introduction and use of IT related to } \\
\text { content development. }\end{array}$ & \multirow{2}{*}{ [59] } \\
\hline & Financial Support & $\begin{array}{l}\text { Our company: } \\
\text { Supports all expenses required for content development. } \\
\text { Allocates a new budget every year for content development. } \\
\text { Can easily obtain financial support for content planning and } \\
\text { development from local banks or other financial institutions. }\end{array}$ & \\
\hline
\end{tabular}

\section{Our management:}

Has the ability to plan and develop various content.

Management Capability

Has technical competence for content planning and development.

Has the ability to manage processes of content development.

Our company:

Encourages members of the organization to think creatively

to promote content innovation.

Innovation Capability

Provides administrative support at all levels to facilitate content innovation.

Provides all possible resources to promote content innovation.

We have increased our market share in the content industry.

We have increased sales and profits.

Sustainability of Content Firm

The contents we develop have a higher success rate than 


\subsection{Content Type: Control Variable}

In this study, the content industry was considered to be an industry without being classified into detailed industries according to specific content. However, if detailed industries or markets exist in research with organizations, there is a limit to generalizing the results derived for the entire industry [63]. In particular, in the content industry, strategies for sustainability of content companies may vary depending on various types of content (education, entertainment, information, broadcasting, etc.). Therefore, in research with organizations, detailed industries or markets within the industry to which the organization belongs are formed, but research with the industry as a whole requires control variables appropriate to the research content [64]. Thus, the content type is set as a control variable.

\section{Analysis Results}

\subsection{Analysis of the Measurement Model}

To confirm the measures used in this study, we evaluated the measurement model by examining (1) overall fitness, (2) reliability, and (3) convergent and discriminant validity. First, confirmatory factor analysis was conducted to obtain the results of several indices to evaluate the overall fitness. The criteria for goodness-of-fit were based on several indicators, including normed fit index (NFI), goodness-of-fit index (GFI), adjusted goodness-of-fit index (AGFI), comparative fit index (CFI), root mean square error of approximation (RMSEA), and relative chi-square ( $\left.\chi^{2} / \mathrm{df}\right)$. The threshold of NFI, GFI, and CFI should be greater than 0.9, and AGFI should be greater than 0.9 [65]. Moreover, the recommended value of RMSEA should be approximately 0.08 or less than 0.05 [66], while the acceptable relative $\chi^{2}\left(\chi^{2} / \mathrm{df}\right)$ is as high as 5 [67]. The results confirmed the overall fitness because all indices used to determine the overall fitness were above their thresholds. Table 3 shows the analysis results.

Table 3. Overall fitness test of the measurement model.

\begin{tabular}{ccccccc}
\hline Model & NFI & GFI & AGFI & CFI & RMSEA & $\chi^{2} / \mathbf{d f}$ \\
\hline Measurement Model & 0.942 & 0.937 & 0.915 & 0.951 & 0.038 & 1.994 \\
Threshold & $\geq 0.90$ & $\geq 0.90$ & $\geq 0.90$ & $\geq 0.90$ & $\leq 0.05$ & $\geq 5.0$ \\
\hline
\end{tabular}

Reliability and convergent validity were evaluated using several measures, including Cronbach's alpha, individual item loading, composite reliability (CR), and average variance extracted (AVE). First, Cronbach's alpha, which measures internal consistency, verifies the extent to which each item measures the latent variable to be measured. The reliability is confirmed when Cronbach's alpha is greater than 0.7 [68]. Table 4 shows that the Cronbach's alpha values of the latent variable range from 0.764 to 0.911 , which exceed the threshold, thereby confirming the reliability.

Convergent validity, which examines the correlation between each measure and the latent variable in the model presented in this study, was assessed using individual item loading, CR, and AVE. Studies have suggested that individual item loading and CR should be greater than 0.7, while AVE should exceed 0.5 [69]. The results show that all items had a loading higher than 0.7, while the CR and AVE of each latent variable exceeded the threshold, implying that the convergent validity of this study is not problematic.

Then, discriminant validity, which confirms the lack of a relationship among measures that theoretically should not be related, was tested. To test discriminant validity, we compared the square root of the AVE with correlations among the latent variables. The square root of AVE should be greater than the values of correlations among the latent variables to demonstrate the discriminant validity of the measurement model. Table 5 shows the result of the discriminant validity test, which confirmed that the square root of the AVEs on the diagonal was greater than all correlations among the latent variables. Therefore, discriminant validity was demonstrated. 
Table 4. Convergent validity and reliability test.

\begin{tabular}{|c|c|c|c|c|c|c|}
\hline Construct & & Items & Mean & S.E. & Loading & $t$-Value \\
\hline \multirow{3}{*}{ Content Development Ability } & \multirow{3}{*}{$\begin{array}{c}\text { AVE }=0.640 \\
C R=0.842 \\
\text { Alpha }=0.845\end{array}$} & cda1 & 4.852 & 0.101 & 0.817 & 15.127 \\
\hline & & cda2 & 5.001 & 0.093 & 0.803 & 10.579 \\
\hline & & cda3 & 5.217 & 0.057 & 0.779 & 19.006 \\
\hline \multirow{3}{*}{ Leadership } & \multirow{3}{*}{$\begin{array}{c}\mathrm{AVE}=0.648 \\
\mathrm{CR}=0.846 \\
\text { Alpha }=0.884\end{array}$} & lea1 & 4.939 & 0.120 & 0.737 & 12.352 \\
\hline & & lea 2 & 5.017 & 0.109 & 0.790 & 16.657 \\
\hline & & lea 3 & 4.810 & 0.089 & 0.881 & 15.102 \\
\hline \multirow{3}{*}{ Technical Support } & \multirow{3}{*}{$\begin{array}{c}\mathrm{AVE}=0.624 \\
\mathrm{CR}=0.833 \\
\text { Alpha }=0.890\end{array}$} & ts1 & 5.805 & 0.076 & 0.757 & 19.217 \\
\hline & & ts2 & 5.288 & 0.058 & 0.819 & 12.433 \\
\hline & & ts3 & 5.383 & 0.046 & 0.793 & 19.976 \\
\hline \multirow{3}{*}{ IT Infrastructure } & \multirow{3}{*}{$\begin{array}{c}\text { AVE }=0.671 \\
C R=0.859 \\
\text { Alpha }=0.793\end{array}$} & itf1 & 4.754 & 0.049 & 0.852 & 18.239 \\
\hline & & itf2 & 5.012 & 0.108 & 0.837 & 20.535 \\
\hline & & itf3 & 5.042 & 0.086 & 0.765 & 11.941 \\
\hline \multirow{3}{*}{ Top Management Support } & \multirow{3}{*}{$\begin{array}{c}\text { AVE }=0.610 \\
\text { CR }=0.824 \\
\text { Alpha }=0.892\end{array}$} & tms1 & 4.267 & 0.114 & 0.808 & 15.409 \\
\hline & & tms2 & 5.228 & 0.059 & 0.746 & 17.289 \\
\hline & & tms3 & 4.839 & 0.081 & 0.788 & 18.122 \\
\hline \multirow{3}{*}{ Financial Support } & \multirow{3}{*}{$\begin{array}{c}\text { AVE }=0.671 \\
\text { CR }=0.859 \\
\text { Alpha }=0.911\end{array}$} & $\mathrm{fs} 1$ & 5.331 & 0.046 & 0.800 & 21.473 \\
\hline & & fs2 & 5.850 & 0.102 & 0.841 & 18.293 \\
\hline & & fs3 & 5.731 & 0.115 & 0.815 & 18.364 \\
\hline \multirow{3}{*}{ Management Capability } & \multirow{3}{*}{$\begin{array}{c}\text { AVE }=0.612 \\
\text { CR }=0.825 \\
\text { Alpha }=0.889\end{array}$} & mc1 & 5.258 & 0.083 & 0.778 & 19.117 \\
\hline & & mc2 & 5.443 & 0.109 & 0.753 & 18.661 \\
\hline & & mc3 & 5.400 & 0.066 & 0.814 & 17.606 \\
\hline \multirow{3}{*}{ Innovation Capability } & \multirow{3}{*}{$\begin{array}{c}\mathrm{AVE}=0.664 \\
\mathrm{CR}=0.856 \\
\text { Alpha }=0.764\end{array}$} & ic1 & 5.698 & 0.078 & 0.809 & 17.158 \\
\hline & & ic2 & 5.739 & 0.011 & 0.824 & 15.700 \\
\hline & & ic3 & 5.107 & 0.041 & 0.811 & 15.812 \\
\hline \multirow{3}{*}{ Sustainability of Content Firm } & \multirow{3}{*}{$\begin{array}{c}\text { AVE }=0.740 \\
\text { CR }=0.895 \\
\text { Alpha }=0.821\end{array}$} & scf1 & 6.057 & 0.087 & 0.802 & 17.438 \\
\hline & & scf2 & 5.231 & 0.105 & 0.876 & 19.197 \\
\hline & & scf3 & 5.852 & 0.088 & 0.900 & 20.825 \\
\hline
\end{tabular}

Note: CR, composite reliability; AVE, average variance extracted.

Table 5. Results for discriminant validity.

\begin{tabular}{|c|c|c|c|c|c|c|c|c|c|}
\hline Construct & 1 & 2 & 3 & 4 & 5 & 6 & 7 & 8 & 9 \\
\hline Content Development Ability & 0.800 & & & & & & & & \\
\hline Leadership & 0.129 & 0.805 & & & & & & & \\
\hline Technical Support & 0.370 & 0.284 & 0.790 & & & & & & \\
\hline IT Infrastructure & 0.218 & 0.251 & 0.345 & 0.819 & & & & & \\
\hline Top Management Support & 0.265 & 0.128 & 0.285 & 0.221 & 0.781 & & & & \\
\hline Financial Support & 0.293 & 0.346 & 0.347 & 0.247 & 0.314 & 0.819 & & & \\
\hline Management Capability & 0.361 & 0.311 & 0.206 & 0.392 & 0.300 & 0.322 & 0.782 & & \\
\hline Innovation Capability & 0.320 & 0.400 & 0.441 & 0.388 & 0.385 & 0.259 & 0.433 & 0.815 & \\
\hline Sustainability of Content Firm & 0.282 & 0.327 & 0.395 & 0.294 & 0.421 & 0.430 & 0.374 & 0.472 & 0.860 \\
\hline
\end{tabular}




\subsection{Structural Model Assessment}

After verifying the measurement model, we developed the SEM to evaluate the proposed hypotheses. Through SEM analysis, we verified the proposed hypotheses with the standardized path coefficient $(\beta)$, indicating the strength of the causal relationships between the constructs. We determined how the exogenous variables help explain the endogenous variable by examining the coefficient of determination $\left(R^{2}\right)$ of the research model.

Figure 2 supports the positive relationships of the proposed hypotheses, with the exception of H1A. First, it was found that among the two human factor variables (i.e., content development ability and leadership), all paths had a positive effect on management and innovation capability except the relationship between content development ability and management capability. The path coefficient between content development ability and innovation capability was 0.216 with $t$-value 2.446 , which was significant at $p<0.05$. Thus, $H 1 B$ was supported. In addition, leadership $(\beta=0.289, t$-value $=3.071)$ was significantly related to management capability, while it had a standardized path coefficient of $0.240(t$-value $=3.693)$ on innovation capability. Thus, $H 2 A$ and $H 2 B$ were supported at $p<0.01$. These results imply that, when members of a content company can continuously develop new content, the company's innovation capacity increases. Moreover, if individual members are leaders in content development, management and innovation capabilities are higher. However, content development ability was not essential for management capability, implying that content development ability and management capability related to content development were negatively correlated. Specifically, while some members focused on content development as their important task, others focused on managing processes or projects related to such development. Therefore, it is difficult to directly link management capability to content development capability.

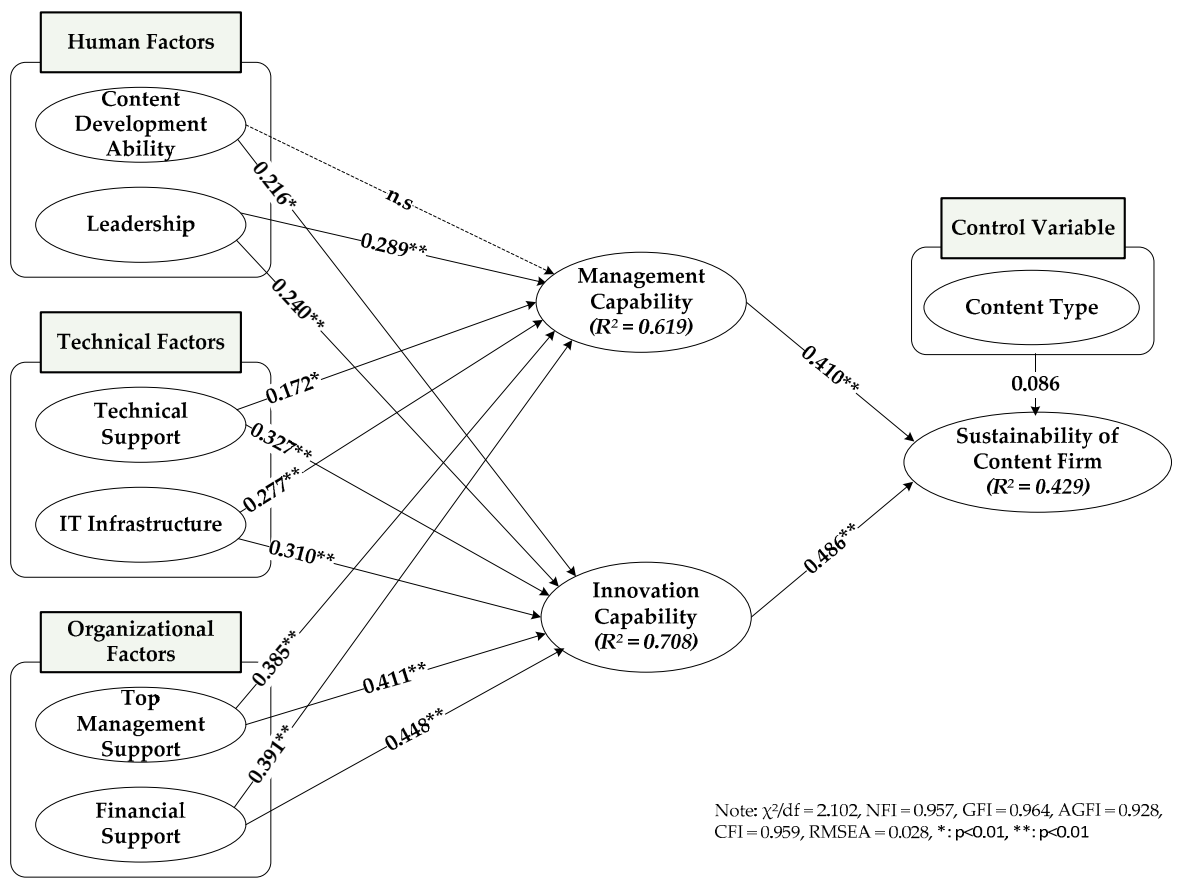

Figure 2. The structural model analysis.

Second, two variables (technical support and IT infrastructure) in the technical factor had a significant effect on both management and innovation capability. Technical support had a path coefficient of 0.172 with $t$-value of 2.095 on management capability, while it had a 0.327 path coefficient with a $t$-value of 4.128 on innovation capability. Thus, $H 3 A$ and $H 3 B$ were supported at $p<0.05$ and $p<0.01$, respectively. Furthermore, the impact of IT infrastructure was significant on both management and innovation capability, with a path coefficient of $0.277(t$-value $=4.802)$ and $0.310(t$-value $=4.446)$; thus, $H 4 A$ and $H 4 B$ were fully 
supported at $p<0.01$. These results imply that the technical support and the IT infrastructure needed for content development are essential for increasing the management and innovative competitiveness of content companies. Accordingly, Shah and Bandi [70] argued that technical support and IT infrastructure (e.g., HW/SW, network, and database) in content companies improve the management and innovative capabilities of content development companies.

Third, the relationships between two variables (top management support and financial support) in the organizational factor and two capabilities (management and innovation) were proven to be significant. The standardized path coefficients of top management and financial support for management capability were $0.385(t$-value $=5.125)$ and 0.391 $(t$-value $=6.983)$, respectively. Thus, $H 5 A$ and $H 6 B$ were supported at $p<0.01$. Moreover, top management support $(\beta=0.411, t$-value $=7.386)$ and financial support $(\beta=0.448$, $t$-value $=9.578)$ were significantly related to innovation capability, $H 5 B$ and $H 6 B$ were thereby supported at $p<0.01$. These results show that, in content firms, the CEOs' and executives' full as well as financial support are essential for reinforcing managerial competence and innovation in content development. Particularly, these two variables have the greatest influence on improving management and innovation capabilities than any other variables of human and technical factors. Therefore, managerial and financial support is necessary to strengthen the managerial and innovative capacity that sustains content companies. This conclusion has also been stated in earlier studies [71].

Finally, both management $(\beta=0.410, t$-value $=8.091)$ and innovation $(\beta=0.486$, $t$-value $=8.994)$ capabilities had a significant positive impact on the sustainability of content firms, emphasizing the importance of management and innovation for content firms to be more successful. Among the two capabilities, innovation had a higher standardized path coefficient than management capability. Therefore, the impact of innovation on the organization indicates the significance of content companies having the willingness and ability to develop new content.

Squared multiple correlations $\left(R^{2}\right)$ for each endogenous variable was another measure, in addition to the path coefficients and their $t$-values, which were used to confirm the research model. The value of $R^{2}$ determines the percentage of variance explained by each variable in the model. For example, six variables in human, technical, and organizational factors explained approximately $61.9 \%$ of the variance in management capability and $70.8 \%$ of the variance in innovation capability, which explained approximately $42.9 \%$ of the variance in sustainability of a content firm. Specifically, $61.9 \%$ and $70.8 \%$ of information management and innovation capability moved in the same direction as the other six variables. Similarly, about $42.9 \%$ of the information held by sustainability of the content firm moves in the same direction as the managerial and innovative capabilities. Figure 2 describes the results of the structural model, and Table 6 summarizes the hypothesis test results.

Table 6. Summary of hypotheses tests.

\begin{tabular}{|c|c|c|c|c|}
\hline Hypothesis & Path & Std. $\beta$ & $t$-Value & Result \\
\hline$H 1 A$ & Content Development Ability $\rightarrow$ Management Capability & 0.068 & 0.933 & NS \\
\hline$H 1 B$ & Content Development Ability $\rightarrow$ Innovation Capability & $0.216^{*}$ & 2.446 & $\mathrm{~S}$ \\
\hline$H 2 A$ & Leadership $\rightarrow$ Management Capability & $0.289^{* *}$ & 3.071 & S \\
\hline$H 2 B$ & Leadership $\rightarrow$ Innovation Capability & $0.240^{* *}$ & 3.693 & S \\
\hline$H 3 A$ & Technical Support $\rightarrow$ Management Capability & $0.172 *$ & 2.095 & S \\
\hline$H 3 B$ & Technical Support $\rightarrow$ Innovation Capability & $0.327^{* *}$ & 4.128 & $\mathrm{~S}$ \\
\hline$H 4 A$ & IT Infrastructure $\rightarrow$ Management Capability & $0.277^{* *}$ & 4.802 & S \\
\hline$H 4 B$ & IT Infrastructure $\rightarrow \rightarrow$ Innovation Capability & $0.310^{* *}$ & 4.446 & S \\
\hline$H 5 A$ & Top Management Support $\rightarrow$ Management Capability & $0.385^{* *}$ & 5.127 & $\mathrm{~S}$ \\
\hline$H 5 B$ & Top Management Support $\rightarrow$ Innovation Capability & $0.411^{* *}$ & 7.386 & S \\
\hline$H 6 A$ & Financial Support $\rightarrow$ Management Capability & $0.391 * *$ & 6.983 & S \\
\hline$H 6 B$ & Financial Support $\rightarrow$ Innovation Capability & $0.448^{* *}$ & 9.578 & S \\
\hline$H 7$ & Management Capability $\rightarrow$ Sustainability of Content Firm & $0.410^{* *}$ & 8.091 & S \\
\hline H8 & Innovation Capability $\rightarrow$ Sustainability of Content Firm & $0.486^{* *}$ & 8.994 & S \\
\hline
\end{tabular}




\section{Discussion}

In the context of the rapid development of ICT and unexpected social environments, such as COVID-19, companies are framing various strategies to increase business performance and sustainability [72]. Increasing demand for diverse content through technologies such as the internet and smartphones has increased the need for empirical studies to investigate the factors affecting sustainability of content firms. In many industries, the importance of an organization's diverse capabilities has already been emphasized [73,74]. However, among the various competencies for the sustainability of content companies in the content industry, there is no research that includes management and innovation capabilities. Since organizational competency plays a very important role in a wide variety of companies and industries, the importance of competency must be emphasized in studying organizational-level behavioral strategies such as business success, agility, and sustainability [75].

This study emphasizes organizational capabilities and provides important value to the content industry. This study therefore developed a model to explain various capabilities and factors to be examined to ensure the sustainability and success of a content company. Based on the literature, this study proposed a model that includes management and innovation capabilities and three main factors (i.e., human, technology, and organization) of content firms that lead to sustainability. The human factor includes content development ability and leadership, the technical factor includes technical support and IT infrastructure, and the organizational factor includes top management support and financial support.

Structural equation analysis was conducted to verify the proposed hypotheses with 255 responses collected through surveys from managers and employees of various content firms. First, the reliability and validity of the measurement model were sufficiently secured. In addition, the structural equation analysis found that, among the proposed research hypotheses, all pathways except the relationship between content development ability and management capability were statistically significant. The findings are consistent with prior studies (e.g., [75]) in that content development ability and leadership have a positive impact on innovation capability, while leadership is positively related to management capability. This finding supports the notion that content firms improve their crucial capabilities when all members of the organization are involved and leaders are competent because they have some knowledge and skills for developing new content.

However, members' content development ability of has no effect on improvement of content management capability. Hence, the ability to develop content is related to an individual's knowledge and skills, while management ability is an overall and comprehensive part of the organization's content development. This result implies that the ability of each member of the organization to develop content is very important from an organizational point of view, but it is difficult to directly relate each individual's ability to the organization's content management ability. Accordingly, Kuo and Ye [76] argued that the entire organization benefits when the specific competencies of individual members of the organization are well-harmonized. Specifically, to develop the management competencies of content companies, harmony and cooperation among members is required based on individual content development capabilities, rather than that of all members of the organization [77]. Hypothesis $2 \mathrm{~A}$ and $2 \mathrm{~B}$ proposed a positive relationship between leadership and both capabilities-management and innovation. Both hypotheses were supported, suggesting that content firm organizations think creating a leadership culture across the organization makes content management and innovation capability stronger. Para-González et al. [78] claim that, when all members of the organization take on the role of leaders, it is easier to innovate and manage organizational tasks or specific projects. Therefore, if members of a content company work as responsible leaders when developing content, their capacity for overall management of new content development and more innovative content development will inevitably increase which is consistent with prior studies (e.g., $[78,79])$. 
Hypothesis $3 \mathrm{~A}$ to $4 \mathrm{~B}$ assessed the relationship between two variables (technical support and IT infrastructure) and two capabilities. These hypotheses were fully supported, indicating that content development management and content innovation capabilities are further strengthened if content companies have a well-equipped infrastructure and support various information technologies, equipment, and procedures related to content development. From this point of view, Guan and Liu [80] argued that information technology support and IT infrastructure must accompany an organization in order to develop capabilities related to specific business processes and tasks. In addition, in order to manage various parts of the content development process and to increase the innovative ability for new content development, it is essential for an organization to secure technical support related to content development and various IT assets related to development.

Hypotheses 5A to 6B proposed top management support and financial support have a significant relationship with both management and innovation capability. Results indicate that these two factors, which make up the organizational factor, were indeed positively related to both capabilities. First, the path coefficient between top management support and management capability was 0.0 .385 ( $t$-value $=5.127$ ), while its path coefficient was $0.411(t$-value $=7.386)$ for innovation capability. Thus, $H 5 A$ and $5 B$ were supported at $p<0.01$. Financial support had the standardized coefficients of $0.391(t$-value $=6.983)$ for management capability and $0.448(t$-value $=9.578)$ for innovation capability. Thus, $H 6 A$ and $6 B$ were supported at $p<0.01$. These results were consistent with prior studies (e.g., $[80,81]$ in that management support is a key factor in developing various competencies of organizations. Content firms should continue to develop new content to sustain their businesses. Therefore, the physical and mental support of management in content development can be an essential factor in enhancing content management capability. In addition, financial support provides content firms with more flexibility that may help firms make better decisions for developing content. Thus, as many studies (e.g., [82]) argue, financial support is required for organizational management capability and innovation. If such support is available within the organization, the organization's content development management and innovation capabilities will be greatly strengthened, which eventually results in a sustainable content business. Finally, two capabilities had a positive impact on the sustainability of content firms. Management and innovation capability had a path coefficient of $0.410(t$-value $=8.091)$ and $0.486(t$-value $=8.994)$, respectively. These results imply that the higher the management competency required to develop content and the innovative competency for the development of new content, the higher the company's sustainability. Furthermore, prior studies (e.g., $[83,84])$ found that a company's success and sustainability depend on the organization's business management system and the continuous innovation of products or services. Therefore, content development management and enhancement of content innovation capabilities are inevitable factors for the sustainability of content companies.

The results of this study can be generalized in several other industries besides content companies. Human, technical, and organizational factors used in this study are generally recognized as elements necessary for strengthening organizational competency in information technology research [84]. For example, there are three types of software development capabilities of IT companies. The factor appears to have an important influence, which is consistent with the results of this study. In addition, even in reinforcing organizational competency in the service industry, various variables related to organizational members and organizational factors were found to have a significant effect on enhancing service company competency [85]. In particular, employee leadership, organizational IT infrastructure, top management support and financial support were found to have a significant impact on organizational capacity building in many industries and research content [86] 


\section{Conclusions}

\subsection{Implications}

This study presents several important academic and practical implications for the success of content companies. First, by systematically analyzing and verifying data collected from members of content firms, this study reveals the important factors that influence the capabilities of content firms that increase their sustainability. Growth of internet technology has led to the use of various content services across regional and time boundaries, but empirical studies on the sustainability of content companies were limited. Thus, this study can form the basis for future research related to the content industry.

Second, most studies on content have studied user behavior for specific content. However, this study integrates human, technology, and organizational factors in the sustainability of content companies as the main study objective, rather than specific content. While most studies have focused on specific content (e.g., games and education) and have addressed the technical aspects of content, this study proposes a theoretical basis for the sustainability of content firms at the organizational and behavioral levels. This area of research still needs extensive investigation. Although investigating specific contents or technological aspects of content strengthens the theoretical research, there are limitations to explaining the sustainability of an organization using specific content or technology alone. Therefore, research from an integrated perspective of organizational members, technology, and organizational factors is needed to study intangible factors such as performance, success, and sustainability of a specific company. This study contributes to the literature by addressing this issue.

Finally, this study theoretically develops measures to assess each latent variable, and it empirically proves their reliability and validity. This study forms the basis for further research on content. Although each variable proposed in this study was based on the literature, it was modified to fit the context and purpose of this study. The measurement variables were developed to assess each variable through a literature review, content validity, and a pilot study to improve accuracy and completeness, which can be used for further empirical studies.

This study offers some practical implications and guidelines for the executives and managers of content firms. First, content firms can increase their capabilities and sustainability in the content business. Regardless of the type of content offered by the firms, all content companies can learn about the human and material factors that strengthen their capabilities. They can thus establish strategies to increase their sustainability. Specifically, the study's findings confirm that the sustainability of an organization is not possible through only a single factor such as a specific project or activity. It is, instead, the result of capacity building through the efficient use of various resources within the organization.

Second, among the human, technical, and organizational factors proposed in this study, it is confirmed that content companies must strengthen top management and financial support. These results suggest that, regardless of the quality of the technology or employees, it is difficult to strengthen the overall management and innovation capabilities without management and financial support. James [87] claimed that increasing organizational capability requires various resource inputs, including efforts from management and budget. A lack of physical collateral makes it difficult to secure funds and receive investment. In response, many countries are providing policy support for content companies to raise funds stably. With financial support and the support of chief executive officers, management and innovation capabilities will be bolstered.

Finally, the study results provide the information necessary for continuous growth in a rapidly changing content-based society where competitive interests start-up content development companies or provide content services. Many start-up companies invest efforts and finance in differentiating and innovating their products or services. However, in the content industry, environmental factors have a great influence on the sustainability of content companies, so the importance of environmental factors surrounding content companies is emphasized rather than types of content that are intangible products. Therefore, 
this study provides important implications for competencies essential for the organization to become a sustainable content company and emphasizes factors other than technology to develop these competencies.

\subsection{Limitations and Future Study}

Despite this study's significance, some limitations must be addressed in future studies on content service. First, this study might suffer from common method bias because the same participants responded to both independent and dependent variables. Therefore, independent and dependent variable responses should be separated in future studies. Second, although the validity of specific firms would strengthen this study, future studies should include more data from various content firms to generalize the study results. Third, this study attempted to explain sustainability in terms of management and innovation capabilities of content companies by using variables included in human, technology, and organizational factors. However, it is difficult to exclude diverse variables and their influences for each factor. That is, as this study focuses on three internal factors, external factors are not included in the scope of the study. Since external factors surrounding an organization can also have an influence on the capacity building of content companies, further research on external factors is also necessary. Given that the sustainability of an organization must include several other factors as well, future studies should propose more diverse internal and external variables through literature studies and interviews with stakeholders. Finally, there exist limitations of this study in data collection and sample size. Although this study has gone through several procedures in data collection to minimize the limitations of online surveys (e.g., data reliability, accuracy, etc.), fundamental differences exist between online and offline data collection methods, so it may be difficult to simply use data collected from the two channels together. Therefore, in future studies, it is necessary to unify the data collection channels to ensure reliability and accuracy of the analytical data.

Author Contributions: As the main contributors, H.P. and S.K. outlined and collected the data, conducted the first round of analysis and discussion, and performed the literature review. M.C. and J.C. reorganized the manuscript, conducted an additional literature review, conceptualized the work, research design, and discussion, and completed a reference check. All authors have read and agreed to the published version of the manuscript.

Funding: This research received no external funding.

Institutional Review Board Statement: Not applicable.

Informed Consent Statement: Not applicable.

Data Availability Statement: Not applicable.

Conflicts of Interest: The authors declare no conflict of interest.

\section{References}

1. Byeon, H. Content management system for content development and data management. J. Digital Conver. 2013, 11, $277-285$.

2. Tsai, H.; Lee, H.; Yu, H. Developing the digital content industry in Taiwan. Rev. Policy Res. 2008, 25, 169-188. [CrossRef]

3. Lee, S.; Cho, K. A study on the reality of IoT device and service information gap in the era of digital transformation. J. Korea Internet Things Soc. 2021, 7, 79-89.

4. Lee, A.R. Investigating the factors influencing the use of live commerce in the un-tact era: Focusing on multidimensional interactivity, presence, and review credibility. Knowl. Manag. Res. 2021, 22, 269-286.

5. Gerard, J.T.; Deborah, J.M.; Seshadri, T.; Zhang, Y. What drives vitality (sharing) of online digital content? The critical role of information, emotion, and brand prominence. Am. Mark. Assoc. 2019, 83, 1-20.

6. Kim, J.; Lee, S.; Geum, Y.; Park, Y. Patterns of innovation in digital content services: The case of app store applications. Innovation 2012, 14, 540-556. [CrossRef]

7. Park, Y.S.; So, S.H. Empirical analysis on technical efficiency and its influential factors of digital content firms: An application of network SBM and panel Tobit model. JIEB 2018, 31, 391-406. [CrossRef]

8. Chen, Y.; Wang, Y.; Nevo, S.; Benitez-Amado, J.; Kou, G. IT capabilities and product innovation performance: The roles of corporate entrepreneurship and competitive intensity. Inf. Manag. 2015, 52, 643-657. [CrossRef] 
9. Wei, J.; Lowry, P.B.; Seedorf, S. The assimilation of RFID technology by Chinese companies: A technology diffusion perspective. Inf. Manag. 2015, 52, 628-642. [CrossRef]

10. Damaševičius, R. On the human, organizational, and technical aspects of software development and analysis. In Information Systems Development; Springer: Boston, MA, USA, 2009; pp. 11-19.

11. Viller, S.; Sommerville, I. Coherence: An approach to representing ethnographic analyses in systems design. Hum. Comput. Interact. 1999, 14, 9-41. [CrossRef]

12. Barney, J.B. Resource-Based theories of competitive advantage: A ten-year retrospective on the resource-based view. J. Manag. 2001, 27, 643-650. [CrossRef]

13. Wang, L.; Li, S.; You, Z. The effects of knowledge transfer on innovation capability: A moderated mediation model of absorptive capability and network reliance. J. High Technol. Manag. Res. 2020, 31, 100371. [CrossRef]

14. Tam, C.; da Costa Moura, E.J.; Oliveira, T.; Varajão, J. The factors influencing the success of on-going agile software development projects. Int. J. Proj. Manag. 2020, 38, 165-176. [CrossRef]

15. Faraji, Z.; Abdolvand, N. Effects of human factor on the success of information technology outsourcing. Int. J. Inform. Technol. Converg. Serv. 2016, 6, 1-12. [CrossRef]

16. CP, Y.H.; Susanto, T.D. E-Leadership: The effect of e-government success in Indonesia. J. Phys. 2019, 1201, 12-25.

17. Maqbool, R.; Sudong, Y. Critical success factors for renewable energy projects; Empirical evidence from Pakistan. J. Clean. Prod. 2018, 195, 991-1002. [CrossRef]

18. Jitpaiboon, T.; Kalaian, S.A. Analyzing the effect of top management support on Information System (IS) performance across organizations and industries using hierarchical linear modeling. J. Int. Inf. Manag. 2005, 14, 131-144.

19. Dinter, B. Success factors for information logistics strategy-An empirical investigation. Decis. Sup. Syst. 2013, 54, 1207-1218. [CrossRef]

20. Kim, S.J. An analysis of the effects of small business ceo's competence types on business performance. J. Ventur. Innov. 2019, 2, 47-64.

21. Moon, Y.B.; Kim, S.H. The effects of strategic orientation on intellectual capital and firm performance. Knowl. Manag. Res. 2012, $13,15-41$.

22. Jeong, K.S. Best practice organizations cultural effects on innovation in small company. J. Ind. Converg. 2015, 13, 41-56.

23. Heo, M.S.; Cheon, M.J. An empirical study on the relationship between employee's agility and work performance: Focused on the agility's influence factors and knowledge-oriented leadership. Knowl. Manag. Res. 2015, 16, 139-172.

24. Zhang, Y.; Sun, J.; Yang, Z.; Wang, Y. Critical success factors of green innovation: Technology, organization and environment readiness. J. Clean. Prod. 2020, 264. [CrossRef]

25. Weill, P.; Subramani, M.; Broadbent, M. Building IT infrastructure for strategic agility. MIT Sloan Manag. Rev. 2002, 44, 57-65.

26. Choi, J.; Kim, Y. Exploring the leading indicator and time series analysis on the diffusion of big data in Korea. J. Technol. Innov. 2018, 26, 57-97. [CrossRef]

27. Kwon, D.H. A study on the meanings of half-life: Alyx and the success factors of VR games. J. Korea Contents Assoc. 2020, 20, 271-284.

28. Skipper, J.B.; Hall, D.J.; Hanna, J.B. Top management support, external and internal organizational collaboration, and organizational flexibility in preparation for extreme events. J. Infor. Sys. Sec. 2009, 5, 32-60.

29. Raghunathan, B.; Raghunathan, T.S. Impact of top management support on IS planning. J. Inform. Syst. 1988, 2, 15-23.

30. Wang, Y.M.; Wang, Y.S.; Yang, Y.F. Understanding the determinants of RFID adoption in the manufacturing industry. Soc. Chang. 2010, 77, 803-815. [CrossRef]

31. Peng, M.W.; Wang, D.Y.L.; Jiang, Y. An institution-based view of international business strategy: A focus on emerging economies. J. Int. Bus. Stud. 2008, 39, 920-936. [CrossRef]

32. Boudreau, M.C.; Robey, D. Enacting integrated information technology: A human agency perspective. Org. Sci. 2005, 16, 3-18. [CrossRef]

33. Chae, H.C.; Koh, C.E.; Prybutok, V.R. Information technology capability and firm performance: Contradictory findings and their possible causes. MIS Q. 2014, 38, 305-326. [CrossRef]

34. Tubbs, S.; Schulz, E. Leadership competencies: Can they be learned? Camb. Bus. Rev. 2005, 3, 7-13.

35. Bueno, C.; Tubbs, S. Identifying global leadership competencies: An exploratory study. J. Am. Acad. Bus. 2004, 5, 80-87.

36. Goleman, D.; Boyatzis, R.E.; McKee, A. The New Leaders: Transforming the Art of Leadership into the Science of Results; Little Brown: London, UK, 2002.

37. Du, W.; Pan, S.L.; Wu, J. How do IT outsourcing vendors develop capabilities? An organizational ambidexterity perspective on a multi-case study. J. Infor. Tech. 2020, 35, 49-65. [CrossRef]

38. Whetton, D.A.; Cameron, K.S. Developing Management Skills, 6th ed.; Pearson-Prentice Hall: Upper Saddle River, NJ, USA, 2005.

39. Byrd, T.A.; Turner, D.E. Measuring the flexibility of information technology infrastructure: Exploratory analysis of a construct. $J$. Manag. Inf. Syst. 2000, 17, 167-208.

40. Broadbent, M.; Weill, P.; Neo, B.S. Strategic context and patterns of IT infrastructure capability. J. Strateg. Inform. Syst. 1999, 8, 157-187. [CrossRef]

41. Jehangir, M.; Dominic, P.D.D.; Langove, N.; Khan, A. Managerial expertise, top management support and learning capacity impact on e-commerce capability and business performance. Int. J. Bus. Innov. Res. 2012, 6, 379-390. [CrossRef] 
42. Lee, S.; Oh, H.Y.; Choi, J. Service design management and organizational innovation performance. Sustainability $2021,13,4$. [CrossRef]

43. Ramirez Lopez, L.J.; Grijalba Castro, A.I. Sustainability and resilience in smart city planning: A Review. Sustainability 2021, 13, 181. [CrossRef]

44. Tu, O.; Raghunathan, B.; Raghunathan, T.S. A discriminant analysis of organizational antecedents of IS performance. J. Inform. Technol. Manag. 1999, 10, 1-15.

45. Çaldağ, M.T.; Gökalp, E. Exploring critical success factors for blockchain-based intelligent transportation systems. Emerg. Sci. J. 2020, 4, 27-44. [CrossRef]

46. Chan, F.T.S.; Chong, A.Y.L. Determinants of mobile supply chain management system diffusion: A structural equation analysis of manufacturing firms. Int. J. Prod. Res. 2013, 51, 1196-1213. [CrossRef]

47. Ko, D.H.; Moon, H.S.; Lee, S.M. A study on the effect of government R\&D supports on firm's innovation activities. KJBA 2015, 28, 1325-1344.

48. Shin, J.K.; Jo, J.I. The relationship between innovation capability of R\&D and the firm's performance: Comparing regional strategy industry with non-regional strategy industry in Daegu. Manag. Inform. Syst. Res. 2011, 30, 211-235.

49. Mostafiz, M.I.; Sambasivan, M.; Goh, S.K. The antecedents and the outcomes of foreign market knowledge accumulation-The dynamic managerial capability perspective. J. Bus. Ind. Mark. 2019, 34, 902-920. [CrossRef]

50. Zawislak, P.A.; Cherubini Alves, A.; Tello-Gamarra, J.; Barbieux, D.; Reichert, F.M. Innovation capability: From technology development to transaction capability. J. Technol. Manag. Innov. 2012, 7, 14-27. [CrossRef]

51. Uhl, A.; Alexander, L. Digital Enterprise Transformation: A Business-Driven Approach to Leveraging Innovative IT; Gower Publishing Company: Surrey, UK, 2014.

52. Wang, C.H.; Lu, I.Y.; Chen, C.B. Evaluating firm technological innovation capability under uncertainty. Technovation 2008, 28, 349-363. [CrossRef]

53. Rajapathirana, R.J.; Hui, Y. Relationship between innovation capability, innovation type, and firm performance. J. Innov. Knowl. 2018, 3, 44-55. [CrossRef]

54. Romijn, H.; Albaladejo, M. Determinants of innovation capability in small electronics and software firms in southeast England. Res. Policy 2002, 31, 1053-1067. [CrossRef]

55. Prybutok, V.R.; Zhang, X.; Ryan, S.D. Evaluating leadership, IT quality, and net benefits in an e-government environment. Inform. Manag. 2008, 45, 143-152. [CrossRef]

56. Chung, D. Something for nothing: Understanding purchasing behaviors in social virtual environments. Cyberpsychol. Behav. 2005, 8, 538-554. [CrossRef]

57. Michel-Verkerke, M.B.; Hoogeboom, A.M. Evaluation of an electronic patient record in a nursing home: One size fits all? In Proceedings of the 45th Hawaii International Conference on System Sciences, Maui, HI, USA, 4-7 January 2012; pp. $2850-2859$.

58. Bhatt, G.D. Exploring the relationship between information technology, infrastructure and business process re-engineering. Bus. Process. Manag. J. 2000, 6, 139-163. [CrossRef]

59. Wu, I.L.; Wu, K.W. A hybrid technology acceptance approach for exploring e-CRM adoption in organizations. Behav. Inform. Technol. 2005, 24, 303-316. [CrossRef]

60. Garrison, G.; Kim, S.H.; Wakefield, R.L. Success factors for deploying cloud computing. Commun. ACM 2012, 55, 62-68. [CrossRef]

61. Rhee, M.; Stephens, A.R. Innovation-oriented technology assimilation strategy and Korean SMEs' enhancing innovation capability, competitive advantage and firm performance. Int. J. Innov. Manag. 2020, 24, 2050081. [CrossRef]

62. Dirsehan, T.; Can, C. Examination of trust and sustainability concerns in autonomous vehicle adoption. Technol. Soc. 2020, 63, 101361. [CrossRef]

63. Sabate, F.; Berbegal-Mirabent, J.; Cañabate, A.; Lebherz, P.R. Factors influencing popularity of branded content in Facebook fan pages. Eur. Manag. J. 2014, 32, 1001-1011. [CrossRef]

64. Löfsten, H.; Lindelöf, P. R\&D networks and product innovation patterns-academic and non-academic new technology-based firms on Science Parks. Technovation 2005, 25, 1025-1037.

65. Bentler, P.M. Comparative fit indexes in structural models. Psychol. Bull. 1990, 107, 238-246. [CrossRef]

66. Browne, M.W.; Cudeck, R. Alternative ways of assessing model fit. In Testing Structural Equation Models; Bollen, K.A., Long, J.S., Eds.; SAGE: Newbury Park, CA, USA, 1993; pp. 136-162.

67. Goodhue, D.L. Understanding user evaluations of information systems. Manag. Sci. 1995, 41, 1827-1844. [CrossRef]

68. Nunnally, N.C. Psychometric Theory; McGraw-Hill: New York, NY, USA, 1978.

69. Chin, W.W.; Marcolin, B.L.; Newsted, P.R. A partial least squares latent variable modeling approach for measuring interaction effects: Results from a montecarlo simulation study and an electronic-mail emotion/adoption study. Inf. Syst. Res. 2003, 14, 189-217. [CrossRef]

70. Shah, V.; Bandi, R. Capability development in knowledge intensive IT enabled services. Eur. J. Work Organ. Psychol. 2003, 12, 418-427. [CrossRef]

71. Al Shaar, E.M.; Khattab, S.A.; Alkaied, R.N.; Manna, A.Q. The effect of top management support on innovation: The mediating role of synergy between organizational structure and information technology. Int. Rev. Manag. Bus. Res. 2015, 4, 499.

72. Park, C.W.; Kang, G.L. A study on the impacts of entrepreneurship and transformational leadership on employment and startup awareness: Mediating effects of corona 19 social issue. Asia Pac. J. Bus. Ventur. Entrep. 2020, 15, 51-63. 
73. Lee, S.; Yoo, J. Determinants of a firm's sustainable competitive advantages: Focused on Korean small enterprises. Sustainability 2021, 13, 346. [CrossRef]

74. Mendoza-Silva, A. Innovation capability: A sociometric approach. Soc. Netw. 2021, 64, 72-82. [CrossRef]

75. Ni, G.; Xu, H.; Cui, Q.; Qiao, Y.; Zhang, Z.; Li, H.; Hickey, P.J. Influence mechanism of organizational flexibility on enterprise competitiveness: The mediating role of organizational innovation. Sustainability 2021, 13, 176. [CrossRef]

76. Kuo, Y.K.; Ye, K.D. How employees' perception of information technology application and their knowledge management capacity influence organizational performance. Behav. Inform. Technol. 2010, 29, 287-303. [CrossRef]

77. Kim, J.S.; Kim, D.J. An exploratory study on developing SCM performance measurements in small and medium enterprises. J. Inform. Sys. 2004, 13, 195-226.

78. Para-González, L.; Jiménez-Jiménez, D.; Martínez-Lorente, A.R. Exploring the mediating effects between transformational leadership and organizational performance. Empl. Relat. 2018, 40, 412-432. [CrossRef]

79. Fonseca, L.; Amaral, A.; Oliveira, J. Quality 4.0: The EFQM 2020 model and industry 4.0 relationships and implications. Sustainability 2021, 13, 3107. [CrossRef]

80. Guan, J.; Liu, J. Integrated innovation between technology and organization. Int. J. Innov. Technol. Manag. 2007, 4, 415-432. [CrossRef]

81. Kim, J.J.; Yi, S.G. The moderating role of the strategies suitability factor for ERP introduction factors and internal performance: Focusing on the small \& medium transportation companies. J. Korea Contents Assoc. 2015, 15, 419-432.

82. Van de Wetering, R.; Mikalef, P.; Helms, R. Driving organizational sustainability-oriented innovation capabilities: A complex adaptive systems perspective. Curr. Opin. Environ. Sustain. 2017, 28, 71-79. [CrossRef]

83. Chen, C.J. Developing a model for supply chain agility and innovativeness to enhance firms' competitive advantage. Manag. Decis. 2019, 57, 1511-1534. [CrossRef]

84. Choi, H.; Yeon, S.; Kim, S. A study on the types of domestic entertainment companies' business diversification strategies: Focusing on the cases of SM, JYP and YG. Korean J. Broadcast. Telecommun. Res. 2019, 107, 63-90.

85. Yoo, S.; Kim, H.M. A study on the effects of psychological capital on pro-social organizational behavior in local subsidiary abroad: Focusing on the type of leadership as a moderator. Int. Commer. Inf. Rev. 2017, 19, 279-304.

86. Lee, E.J. Factors affecting the introduction of the internet by fashion companies. J. Korean Home Econ. Assoc. 2008, 46, 87-96.

87. James, R. Records management in the Cloud? Records management IS the Cloud! Bus. Inform. Rev. 2010, 27, 179-189. [CrossRef] 